\title{
PENGEMBANGAN MODUL BERBASIS MASALAH UNTUK MENINGKATKAN KEMAMPUAN PEMECAHAN MASALAH MATEMATIS SISWA KELAS VII SMP
}

\section{PROBLEM BASED MODEL DEVELOPMENT TO IMPROVE MATHEMATICAL PROBLEM SOLVING ABILITY FOR SEVENTH GRADE SMP STUDENT}

\author{
Retno Amalia1), Thamrin Tayeb2), Andi Ika Prasasti Abrar ${ }^{3)}$ \\ 1,2,3)Fakultas Tarbiyah dan Keguruan Universitas Islam Negeri Alauddin Makassar \\ retnoamalia547@gmail.com ${ }^{11}$, thamrin.tayeb@gmail.com ${ }^{2)}$ asty math03@yahoo.co.id ${ }^{3)}$
}

\begin{abstract}
Abstrak
Penelitian ini bertujuan untuk mengembangkan modul berbasis masalah untuk meningkatkan kemampuan pemecahan masalah matematika siswa pada materi aritmetika sosial yang valid, praktis, dan efektif di kelas VII SMPN 7 Cenrana kabupaten Maros. Dalam penelitian ini penulis menggunakan model pengembangan Plomp yang terdiri dari beberapa fase yaitu: Preliminary Investigation (investigasi awal), Design (desain), Realization (realisasi), Test, Evaluation and Revision (tes, evaluasi dan revisi), dan Implementation (implementasi). Subjek penelitian ini adalah siswa kelas VII D SMPN 7 Cenrana. Instrumen penelitian yang digunakan adalah lembar validasi ahli, angket respons siswa dan guru, lembar observasi kemampuan guru dalam mengelola pembelajaran, lembar observasi aktivitas siswa dan tes kemampuan pemecahan masalah. Berdasarkan hasil uji coba terbatas yang dilakukan, diperoleh bahwa (1) hasil validasi modul adalah 4,4 pada kategori sangat valid, (2) praktis karena persentase rata-rata untuk respons siswa adalah $85,53 \%$ pada kategori positif dan persentase rata-rata respons guru adalah $84 \%$ pada kategori sangat positif. (3) Efektif karena telah memenuhi tiga kriteria yaitu rata-rata kemampuan guru dalam mengelola pembelajaran adalah 4,6 pada kategori sangat baik, persentase rata-rata aktivitas siswa adalah $75,7 \%$ pada kategori sangat baik, dan persentase ketuntasan belajar siswa pada kategori tinggi serta mencapai ketuntasan klasikal yaitu $81,5 \%$. Sehingga dapat disimpulkan bahwa berbasis masalah pada materi aritmatika sosial di kelas VII SMPN 7 Cenrana Kabupaten Maros telah memenuhi kriteria kevalidan, kepraktisan, dan keefektifan.
\end{abstract}

Kata Kunci: modul, berbasis masalah, aritmatika sosial, kemampuan pemecahan masalah matematis.

\begin{abstract}
This research aims to develop a problem-based module to promote seventh grader's mathematical problem-solving ability at SMPN 7 Cenrana in Maros Regency that meets the criteria of product validity, practicality, and effectiveness. It adopts Plomp Research \& Development model which consists of several development phases namely preliminary investigation, design, realisation, test, evaluation and revision and implementation. The product was tested on students of class VII D of SMPN 7 Cenrana. This research employs some instruments to gather its data, such as expert validation sheet, student response questionnaire, teacher response questionnaire, teacher's media management ability observation sheet, student activity observation sheet and problem-solving tests. The results of the limited trials show some important research findings as follows: (1) the module is categorised valid, as indicated by validity value 4.4 and scores within an interval of $4.3 \leq$ ? $\leq$
\end{abstract}


5; (2) the module has met practicality criteria owning to student's positive response (85.53\% and teacher's highly positive response (84\%); (3) the module is proclaimed effective as it has fulfilled three requirements, addressing teacher's complimentary media management ability (4.6), high level of student's activity (75.7\%), as well as student's unit completeness (81.5\%). In summary, the problem-based module to promote seventh grader's mathematical problemsolving ability at SMPN 7 Cenrana in Maros Regency has successfully fulfilled the criteria of validity, practicality and effectiveness.

Keywords: module, problem-based, social arithmetic, mathematical problem-solving ability

How to Cite: Amalia, R., Tayeb, T., \& Abrar, A.I.P. (2019). Pengembangan modul berbasis masalah untuk meningkatkan kemampuan pemecahan masalah matematis siswa kelas VII SMP. Al-Asma: Journal of Islamic Education, 1(2), 136-147.

\section{PENDAHULUAN}

Pengetahuan manusia tentang matematika memiliki peran yang penting dalam kehidupan. Berdasarkan peran tersebut, matematika merupakan bidang studi yang selalu diajarkan di setiap jenjang pendidikan di Indonesia. Tujuan pembelajaran matematika di sekolah adalah agar siswa memiliki kemampuan pemahaman matematis dan memanfaatkan kegunaan matematika dalam kehidupan sehari-hari (Wulandari, 2016).

Berdasarkan hasil wawancara dengan ibu Siti Ramlah, S.Pd sebagai guru matematika kelas VII SMPN 7 Cenrana, diperoleh informasi bahwa kemampuan siswa dalam menguasai materi pembelajaran matematika belum memuaskan, terbukti dari nilai ulangan semester lalu dari 26 siswa 65\% diantaranya memperoleh nilai yang masih dibawah nilai KKM. Hal ini diakibatkan oleh kurangnya perhatian siswa dalam mengikuti proses pembelajaran, kurangnya komunikasi siswa dengan guru, kurangnya motivasi siswa untuk belajar, serta kurangnya penguasaan konsep dan prestasi belajar siswa pada pelajaran matematika.

Kemampuan matematika dapat diklasifikasikan dalam lima kompetensi utama yaitu: pemahaman matematika, pemecahan masalah matematika, koneksi matematika, komunikasi matematika, dan penalaran matematika (Soemarmo, Utari dan Hendriana, 2014). Salah satu kemampuan matematika yang diharapkan dalam pembelajaran matematika adalah kemampuan pemecahan masalah. Pemecahan masalah merupakan kompetensi strategik yang ditunjukkan siswa dalam memahami, memilih pendekatan dan strategi pemecahan, dan menyelesaikan model permasalahan. Kemampuan pemecahan masalah dapat dikatakan sebagai suatu keterampilan dasar yang harus dimiliki seseorang, karena setiap manusia harus mampu memecahkan masalahnya sendiri (Al Atiyah, 2014).

Pemecahan masalah matematika sering kita jumpai dalam bentuk soal cerita dalam kehidupan sehari-hari (Al Atiyah, 2014). Ini menunjukkan bahwa matematika dapat dilihat secara realistis. Namun, pada kenyataannya di lapangan terdapat masalah dalam pembelajaran matematika yaitu kurangnya kemampuan siswa dalam memecahkan masalah matematika. Berdasarkan hasil observasi yang dilakukan peneliti di kelas VII di SMPN 7 Cenrana, bahwa kemampuan pemecahan masalah matematika siswa masih relatif rendah. 
Gejala-gejala yang ditunjukkan antara lain:

1. Dari 27 siswa, $65 \%$ diantaranya belum bisa menyelesaikan soal-soal yang tingkat kesulitannya lebih tinggi.

2. Dari 27 siswa, $65 \%$ belum bisa mengidentifikasi apa yang diketahui dan yang ditanyakan dari soal.

3. Dari 27 siswa, $70 \%$ hanya menghafal konsep sehingga belum bisa menggunakan konsep tersebut untuk memecahkan persoalan yang berhubungan dengan konsep yang telah dimiliki.

4. Dari 27 siswa, $70 \%$ menjawab soal tanpa menggunakan langah-langkah umum pemecahan masalah.

Guru telah melakukan usaha untuk meningkatkan kemampuan pemecahan masalah matematika siswa. Guru adalah figur manusia yang memegang peran penting dalam pendidikan. Pendidik atau guru merupakan tenaga profesional yang bertugas merencanakan dan melaksanakan proses kegiatan belajar mengajar di kelas dan menilai hasil pembelajaran. Suatu pembelajaran tidak dapat terlepas dari sumber belajar. Salah satu sumber belajar yang sering digunakan guru adalah buku pelajaran. Bahan ajar merupakan salah satu komponen sistem pembelajaran yang memegang peran penting dalam membantu siswa mencapai standar kompetensi dan tujuan pembelajaran. Salah satu masalah penting yang sering dihadapi guru dalam kegiatan pembelajaran adalah memilih dan mementukan model pembelajaran (Khadijah, 2017).

Selain menentukan model pembelajaran, bahan ajar merupakan salah satu solusi untuk membantu menyelesaikan masalah yang ada di kelas. Untuk mengembangkan bahan ajar, referensi dapat diperoleh dari berbagai sumber baik itu berupa pengalaman ataupun pengetahuan sendiri, ataupun dari narasumber ahli maupun narasumber teman sejawat, dan dapat juga diperoleh dari buku-buku, media massa, internet, dan sebagainya (Simanungkalit, 2016).

Alasan peneliti ingin mengembangkan bahan ajar berupa modul karena bahan ajar yang digunakan di sekolah berupa buku paket dan modul. Meskipun modul yang ada tidak digunakan lagi dikarenakan tidak sesuai dengan kurikulum yang digunakan untuk kelas VII dan buku paket hanya digunakan pada saat pembelajaran dan tidak termasuk buku pegangan siswa. Modul adalah suatu bahan ajar pembelajaran yang isinya relatif singkat dan spesifik yang disusun untuk mencapai tujuan pembelajaran (Meyer, 1978). Modul biasanya memiliki suatu rangkaian kegiatan yang terkoordinir dengan baik berkaitan dengan materi dan media serta evaluasi.

Pengembangan bahan ajar harus disusun berdasarkan model pembelajaran yang tepat juga. Penggunaan model pembelajaran yang tidak sesuai dengan perkembangan siswa akan berdampak terhadap tahap perkembangan belajar siswa.

Model pembelajaran yang berkaitan dengan cara memecahkan masalah adalah model pembelajaran berbasis masalah (Problem Based Learning). Pemilihan PBL dalam mengembangkan bahan ajar berupa modul ini didorong dan didasari oleh beberapa argumen. Pertama, PBL merupakan model pembelajaran yang membantu guru untuk mengaitkan materi dengan situasi nyata siswa, kedua, dengan PBL siswa dapat memfasilitasi keberhasilan memecahkan masalah, komunikasi, kerja kelompok, dan keterampilan interpersonal dengan baik. Ketiga, PBL dapat dapat menciptakan kondisi bagi siswa untuk mengembangkan dan mempertahankan keterampilan belajar mandiri 
sehingga pembelajaran lebih bermakna dan keempat, pelaksanaan model pembelajaran yang menerapkan PBL, siswa akan bekerja dalam tim untuk memecahkan masalah dunia nyata (Yustianingsih \& Syarifuddin, 2017). Pembelajaran berbasis masalah merupakan pembelajaran yang menuntut aktivitas mental siswa secara optimal dalam belajar berpikir kritis, keterampilan pemecahan masalah, dan memperoleh pengetahuan mengenai esensi dari materi pelajaran dalam memahami suatu konsep, prinsip, dan keterampilan matematis siswa berbentuk ill-stucture atau open-ended melalui stimulus (Sumartini, 2016).

Pembelajaran dengan sistem modul yang disertai metode PBL (Problem Based Learning) memberi kesempatan kepada siswa untuk lebih mengeksplorasikan berdasarkan kemampuannya sehingga tercipta belajar lebih mandiri dan hal ini akan mengubah orientasu belajar yang semula hanya berpusat pada guru kemudian berubah menjadi berpusat pada kegiatan siswa sendiri (Syahrir, 2015).

\section{METODE PENELITIAN}

Jenis penelitian yang digunakan adalah penelitian dan pengembangan atau Research and Development (R\&D). Research and Development adalah metode penelitian yang digunakan untuk menghasilkan produk tertentu, dan menguji keefektifan produk tersebut.

Penelitian ini merupakan penelitian pengembangan yang mengacu pada model pengembangan Plomp. Penelitian ini menggunakan model pengembangan Plomp karena tahapan yang ada pada model ini sangat cocok dalam penelitian dan pengembangan perangkat pembelajaran yang akan dilakukan oleh peneliti. Model ini terdiri dari 5 fase yaitu Preliminary Investigation (fase investigasi awal), Design (fase desain), Realization (fase realisasi), Test, Evaluation and Revision (fase tes, evaluasi dan revisi), dan implementation (fase implementasi) (Arsyad, 2015).

Subjek uji coba dalam penelitian ini adalah siswa kelas VII D SMPN 7 Cenrana. Instrumen pengumpulan data yang digunakan dalam penelitian ini adalah lembar validasi ahli, lembar observasi kemampuan guru dalam mengelola pembelajaran, lembar observasi aktivitas siswa, angket respons guru, angket respons siswa, dan tes kemampuan pemecahan masalah.

\section{HASIL DAN PEMBAHASAN}

Pengembangan modul matematika berbasis masalah pada penelitian ini menggunakan model pengembangan Plomp yang terdiri dari 5 fase yaitu Preliminary Investigation (fase investigasi awal), Design (fase desain), Realization (fase realisasi), Test, Evaluation and Revision (fase tes, evaluasi dan revisi), dan implementation (fase implementasi). Penjelasan tahap-tahap pengembangan tersebut dijelaskan lebih lanjut sebagai berikut:

1. Preliminary Investigation (fase investigasi awal)

a. Mengidentifikasi Informasi dan Analisis Informasi

Pada fase ini peneliti telah melakukan identifikasi informasi dan analisis informasi sebagai langkah awal untuk menentukan masalah dalam pengembangan modul. Adapun hasil dari langkah awal ini adalah sebagai berikut: 
1) Analisis Proses Pembelajaran

Analisis proses pembelajaran dilakukan dengan melakukan pengamatan saat proses pembelajaran berlangsung untuk mengidentifikasi masalah awal yang akan dikaji lebih mendalam. Hasil yang didapatkan pada tahap analisis ini yaitu siswa kurang berperang aktif dalam kelas selama proses pembelajaran yang mengakibatkan proses belajar masih berpusat pada guru. Hal ini terlihat dari kurangnya partisipasi siswa dalam pembelajaran, misalnya aktif dalam mengerjakan soal di papan tulis atau mengajukan pertanyaan mengenai materi yang belum mereka pahami. Pembelajaran yang berpusat pada guru disebabkan karena kemampuan awal siswa yang masih kurang sehingga guru harus menjelaskan kembali materi prasyarat dari awal. Masalah lain yang diperoleh adalah kurangnya sarana yang mendukung proses pembelajaran dalam hal ini buku pegangan siswa yang mengakibatkan siswa kurang mampu untuk belajar mandiri dan harus bergantung pada guru.

2) Analisis Siswa

Pada analisis siswa, peneliti menelaah latar belakang pengetahuan siswa dan tingkat perkembangan kognitifnya. Hasil analisis untuk mengetahui kemampuan awal siswa terhadap mata pelajaran matematika pada materi aritmetika sosial diperoleh bahwa sebagian besar siswa kurang mengusai materi prasyarat yakni bentuk aljabar dan Sistem Persamaan Linear Dua Variabel (SPLDV). Selain itu, sebagian siswa masih belum bisa mengidentifikasi soal yang ada. Hal ini terlihat ketika peneliti mengamati siswa saat proses belajar di kelas. Siswa kurang mampu belajar mandiri, terlihat dari jawaban mereka dalam tes yang hampir sama meskipun jawaban tersebut kurang tepat.

3) Analisis Materi

Kegiatan yang dilakukan pada tahap ini adalah mengidentifikasi, merinci, dan menyusun secara sistematis materi utama yang dipelajari siswa. Selanjutnya materi tersebut disusun secara sistematis. Materi pelajaran dalam penelitian ini adalah materi aritmatika sosial dengan standar isi kurikulum 2013. Garis besar pada materi aritmetika sosial dengan indikator-indikator ketercapaian antara lain harga penjualan, harga pembelian, untung, rugi, diskon, bruto, tara, netto, bunga tunggal dan pajak.

b. Pengkajian Model Pembelajaran dan Teori-teori Belajar yang Relevan

Menurut Jean Peaget tahap operasional formal adalah periode terakhir perkembangan kognitif. Tahap ini mulai dialami anak dalam usia sebelas tahun (saat pubertas) dan terus berlanjut sampai dewasa. Hal ini sesuai dengan usia siswa kelas VII yang berada pada rentang usia 11-18 tahun yang menjadi subjek penelitian.

Karakteristik tahap ini adalah diperolehnya kemampuan untuk berpikir secara abstrak, menalar secara logis, dan menarik kesimpulan dari informasi yang tersedia. Sedangkan, model berbasis masalah dalam pembelajaran dapat mengantarkan siswa untuk menguasai dasar-dasar matematika yang berkaitan dengan pemecahan masalah sehari-hari agar siswa dapat diarahkan kepemikiran-pemikiran penerapan matematika baik secara konseptual untuk memecahkan masalah gejala alam maupun secara praktis untuk mengembangkan ilmu pengetahuan dan teknologi.

c. Mendefinisikan dan Membatasi Masalah serta Merencanakan Kegiatan Lanjutan

Setelah melakukan identifikasi informasi dan analisis informasi serta pengkajian model pembelajaran dan teori-teori belajar yang relevan maka masalah yang diperoleh yaitu kurangnya sarana pendukung dalam hal ini bahan ajar berupa modul yang 
digunakan dalam proses pembelajaran yang dapat membantu siswa untuk belajar secara aktif dan mandiri serta meningkatkan kemampuan pemecahan masalah matematika materi aritmetika sosial. Kegiatan lanjutan adalah mengembangkan sebuah modul yang sesuai dengan kebutuhan yaitu berupa modul matematika berbasis masalah.

\section{Design (Fase Desain)}

Fase selanjutnya adalah fase desain, pada fase desain ini peneliti mulai merancang modul dengan menggunakan model problem based learning (PBL) pada materi aritmatika sosial kelas VII. Pada fase ini, dirancang desain dan sistematika perangkat pembelajaran yang akan digunakan dalam pembelajaran yang mencakup beberapa aspek, yaitu:

a. Pemilihan Format

Hasil Pemilihan format rencana pelaksanaan pembelajaran (RPP) disesuaikan dengan sintaks pembelajaran matematika berbasis model berbasis masalah yang didalamnya memuat kompetensi inti, kompetensi dasar, indikator, tujuan pembelajaran, materi ajar, penilaian, kegiatan pembelajaran, dan sumber bacaan. Pelaksanaan pembelajaran meliputi: model, pendekatan metode, dan alat sumber belajar. Skenario pembelajaran terdiri dari kegiatan pendahuluan, kegiatan inti dan penutup. Di dalam RPP khususnya pada kegiatan inti dimasukkan model pembelajaran berbasis masalah sedangkan format modul dan tes kemampuan pemecahan masalah dibuat berwarna, teratur, rapi, terstruktur sehingga siswa akan tertarik, termotivasi dan mudah untuk belajar.

b. Pembuatan Produk

Pada fase desain telah dirancang modul pembelajaran yang akan dibuat, kemudian pada tahap ini dimulailah pembuatan produk yang sesuai dengan struktur yang telah dirancang tersebut. Tahap pertama yaitu membuat sampul modul yang telah dirancang kemudian tahap kedua membuat isi modul yang strukturnya juga telah disesuaikan dengan struktur modul yang telah dirancang sebelumnya.

c. Rancangan Awal Modul

1) Rancangan Sampul Modul

Peneliti mencari informasi dari berbagai sumber terkait dengan cara membuat sampul modul. Melihat dari contoh sampul buku atau pun contoh sampul bahan ajar lainnya yang telah ada, sehingga peneliti bisa menghasilkan rancangan yang terlihat lebih bagus dan terlihat menarik dengan kombinasi warna dan gambar yang sesuai sehingga siswa tertarik untuk menggunakan modul sebelum melihat isi bahan ajar tersebut.

2) Rancangan Isi Modul

Pada rancangan isi, pemilihan dan penentuan bahan dimaksudkan untuk memenuhi salah satu kriteria bahwa suatu modul harus menarik dan dapat membantu siswa untuk mencapai kompetensi. Dengan demikian, modul dibuat sesuai dengan kebutuhan dan kecocokan dengan kompetensi dasar yang akan diraih oleh siswa. Dalam hal ini peneliti memilih modul dengan menggunakan model pembelajaran berbasis masalah pada materi aritmatika sosial kelas VII. Modul ini dirancang berdasarkan kurikulum matematika yang berlaku sesuai dengan jenjang pendidikan yaitu SMP. Modul ini berisi masalah nyata, materi aritmatika sosial, kegiatan belajar yang memuat sintaks model pembelajaran 
berbasis masalah, contoh soal, evaluasi pada setiap sub materi, rangkuman dan uji kompetensi yang terletak diakhir bab. Modul ini dilengkapi dengan 5 langkah atau sintaks model pembelajaran berbasis masalah yang dituangkan ke dalam modul yaitu orientasi siswa pada masalah, mengorganisasi siswa untuk belajar, membimbing penyelidikan individual maupun kelompok, mengembangkan dan menyajikan hasil karya, dan menganalisis dan mengevaluasi proses pemecahan masalah. Di dalam modul ini, terdapat kata "Mengamati Masalah" merupakan bagian yang mewakili fase pertama dalam sintaks berbasis masalah yaitu orientasi siswa pada masalah. "Mari Berdiskusi" merupakan bagian yang mewakili fase kedua dalam sintaks berbasis masalah yaitu mengorganisasi siswa untuk belajar. "Menggali Informasi" merupakan bagian yang mewakili fase ketiga dalam sintaks berbasis masalah yaitu membimbing penyelidikan individu atau kelompok. "Membuat Laporan" merupakan bagian yang mewakili fase keempat dalam sintaks berbasis masalah yaitu mengembangkan dan menyajikan hasil karya. "Mari Berbagi" merupakan bagian yang mewakili fase kelima dalam sintaks berbasis masalah yaitu menganalisis dan mengevaluasi proses pemecahan masalah. Inilah yang merupakan ciri khas modul yang dihasilkan pada penelitian ini yang cukup berbeda dengan modul yang digunakan siswa sebelumnya di sekolah.

d. Penyusunan Instrumen Penelitian

Instrumen yang digunakan dalam penelitian ini terdiri 3 aspek yaitu:

1) Aspek kevalidan, terdiri dari:

a) Lembar validasi modul

b) Lembar validasi lembar angket respons siswa

c) Lembar validasi lembar angket respons guru

d) Lembar validasi lembar observasi aktivitas siswa

e) Lembar validasi lembar observasi kemampuan guru mengelola pembelajaran

f) Lembar validasi RPP

g) Lembar validasi tes kemampuan pemecahan masalah

2) Aspek kepraktisan, terdiri dari:

a) Lembar angket respons guru

b) Lembar angket respons siswa

3) Aspek keefektifan, terdiri dari:

a) Lembar observasi kemampuan guru mengelola pembelajaran

b) Lembar observasi aktivitas siswa

c) Tes kemampuan pemecahan masalah

3. Realization (Fase Realisasi)

Pada tahap pengembangan ini bertujuan untuk menghasilkan perangkaat pembelajaran matematika berbasis masalah yang telah direvisi sehingga layak digunakan dalam penelitian atau diujicobakan. Kegiatan yang dilakukan pada tahap ini adalah: validasi ahli dan uji coba.

4. Test, Evaluation and Revision (fase tes, evaluasi dan revisi)

a. Validasi Ahli

1) Validator

Pada tahap ini, dilakukan validasi oleh ahli terkait modul yang telah dibuat pada fase realisasi. Ahli yang melakukan validasi terhadap bahan ajar dan instrument penelitian 
adalah dua orang Dosen Fakultas Tarbiyah dan Keguruan UIN Alauddin Makassar yaitu Suharti, S.Pd.,M.Pd (Validator I) dan Baharuddin, S.Pd., M.Pd (Validator II). Validasi yang dilakukan oleh tim ahli pada validasi produk adalah validasi isi dari segi substansi, konstruk, bahasa, dan praktikalitas. Kemudian validasi yang dilakukan oleh tim ahli pada validasi desain adalah yang berhubungan dengan tampilan fisik bahan ajar yaitu desain sampul, tampilan isi buku, konteks masalah dan gambar, dan kepadatan isi materi. Melalui pertimbangan ahli ini diharapkan kualitas produk yang dibuat dapat teruji secara teoritis dan rasional serta menarik baik dari segi tampilan fisik maupun tampilan isi materi. Validasi ini dilakukan dengan mendatangi langsung ahli untuk menilai dan memvalidasi produk yang dibuat dengan memperlihatkan rancangan desain dan diminta untuk menilainya sehingga selanjutnya dapat diketahui letak kelemahan dan kelebihannya.

Berdasarkan hasil analisis validasi yang telah dilakukan, data menunjukkan bahwa modul, Rencana Proses Pembelajaran (RPP), Tes kemampuan pemecahan masalah, angket respons guru, angket respons siswa, lembar observasi aktivitas siswa dan kemampuan guru dalam mengelola peembelajaran menunjukkan rata-rata dari keseluruhan aspek adalah 4,4 sehingga berada pada kategori sangat valid karena setiap aspek pada setiap jenis lembar validasi berada pada inteval $4,3 \leq M \leq 5$. Selain itu, semua validator memberikan kesimpulan bahwa perangkat yang telah dikembangkan adalah baik dan dapat digunakan dengan sedikit revisi.

2) Revisi Bahan Ajar dan Instrumen

a) Validasi Pertama

Proses validasi yang pertama kali di lakukan dengan mengajukan rancangan awal modul dengan menggunakan model pembelajaran berbasis masalah yang telah dikembangkan pada bagian awal kepada tim validator. Adapun deskripsi masukan yang diberikan oleh validator sebagai berikut:

Tabel 1. Hasil Validasi yang dilakukan pada Proses Validasi Pertama Meliputi Saran-Saran dari Tim Validator

\begin{tabular}{|c|c|}
\hline Aspek & Saran Perbaikan \\
\hline Modul & $\begin{array}{l}\text { 1. Sampul yang digunakan masih perlu perbaikan. } \\
\text { Fokuskan modul ini hanya digunakan untuk SMP } \\
\text { atau MTs } \\
\text { 2. Mengambil sebagian gambar dari dokumentasi oleh } \\
\text { si penulis } \\
\text { 3. Memperbaiki kalimat dari isi modul yang kurang } \\
\text { tepat dan salah ketikan }\end{array}$ \\
\hline RPP & $\begin{array}{l}\text { 1. Kegiatan inti dalam RPP sebaiknya di sesuaikan } \\
\text { dengan sintaks pembelajaran berbasis masalah } \\
\text { 2. Menyusun kata untuk pencapaian kompetensi } \\
\text { 3. Sesuaikan dengan kurikulum } 2013\end{array}$ \\
\hline $\begin{array}{l}\text { Tes Kemampuan } \\
\text { Pemecahan Masalah }\end{array}$ & $\begin{array}{l}\text { 1. Soal-Soal yang dibuat harus memenuhi semua } \\
\text { 143ahasa143or dalam pembelajaran. } \\
\text { 2. Perlu ditambahkan lagi soalnya }\end{array}$ \\
\hline $\begin{array}{l}\text { Angket } \\
\text { Siswa }\end{array}$ & $\begin{array}{l}\text { Memperbaiki beberapa kata-kata yang masih kurang } \\
\text { jelas dan sesuaikan dengan kaidah bahasa Indonesia }\end{array}$ \\
\hline
\end{tabular}




\begin{tabular}{ll}
\hline $\begin{array}{l}\text { Angket Respons } \\
\text { Guru }\end{array}$ & $\begin{array}{l}\text { Usahakan kata-kata yang ada di dalamnya di sesuaikan } \\
\text { dengan kaidah bahasa Indonesia. }\end{array}$ \\
\hline $\begin{array}{l}\text { Lembar Observasi } \\
\text { Aktivitas Siswa }\end{array}$ & Memperbaiki beberapa kata yang masih kurang tepat \\
\hline $\begin{array}{l}\text { Lembar Observasi } \\
\text { Kemampuan Guru }\end{array}$ & Memperbaiki beberapa kata yang masih kurang tepat \\
Dalam Mengelola \\
Pembelajaran
\end{tabular}

b) Validasi Tahap Kedua

Proses validasi yang kedua dilakukan dengan mengajukan hasil revisi dalam proses validasi pertama sesuai dengan catatan yang diberikan pada proses validasi pertama kepada tim validator. Deskripsi masukan yang diberikan oleh validator sebagai berikut:

Tabel 2. Hasil Validasi yang dilakukan pada Proses Validasi Kedua meliputi Saran-Saran dari Tim Validator

\begin{tabular}{ll}
\hline Aspek & \multicolumn{1}{c}{ Saran Perbaikan } \\
\hline Modul & 1. Mencari desaian warna yang menarik \\
& 2. Menambahkan beberapa prolog \\
& 3. Memperjelas gambar pada lembar informasi isi \\
& modul \\
RPP & Memperbaiki beberapa kata yang masih kurang tepat \\
& dan sesuaikan dengan kaidah 144ahasa indonesia \\
\hline
\end{tabular}

Berdasarkan data di atas dapat disimpulkan bahwa rata-rata penilaian dari para ahli validator berada pada kategori "sangat valid" hal ini menunjukkan bahawa modul, Rencana Proses Pembelajaran (RPP), tes kemampuan pemecahan masalah, angket respons siswa, angket respons guru, lembar observasi aktivitas siswa, dan lembar observasi kemampuan guru dalam mengelola pembelajaran tersebut layak untuk diujicobakan.

b. Uji Coba Terbatas

Modul yang telah direvisi berdasarkan saran-saran dan masukan selanjutnya diujicobakan pada siswa kelas VII D SMPN 7 Cenrana. Uji coba tersebut dilakukan untuk melihat kepraktisan dan keefektifan modul yang dikembangkan..

1) Analisis Data Kepraktisan

a) Angket Respon Siswa

Angket respons siswa diberikan kepada 27 orang siswa kelas VII setelah mengikuti seluruh rangkaian pembelajaran dengan menggunakan modul berbasis masalah pada pokok bahasan aritmatika sosial. Berdasarkan hasil analisis diperoleh bahwa persentase rata-rata respons siswa terhadap kegiatan pembelajaran dengan menggunakan modul memiliki nilai lebih besar dari 80\%. Dari keseluruhan aspek yang ditanyakan, presentasi respons siswa adalah 85,53\%. Angka tersebut berada pada interval $70 \% \leq R S<85 \%$ dengan kategori positif. 
b) Angket Respon Guru

Angket respons guru diberikan kepada guru setelah kegiatan mengajar dilaksanakan menggunakan modul berbasis masalah yang telah dikembangkan. Dari keseluruhan aspek yang ditanyakan terlihat bahwa total respons guru terhadap kegiatan pembelajaran dengan menggunakan modul memiliki nilai sebesar 84\%. Angka tersebut berada pada interval $70 \% \leq R S \leq 85 \%$ dengan kategori setuju.

2) Analisis Data Keefektifan

a) Kemampuan Guru dalam Mengelola Pembelajaran

Tujuan analisis kemampuan guru dalam mengelola pembelajaran adalah untuk melihat sejauh mana kemampuan guru mengelola pembelajaran matematika dengan menggunakan modul berbasis masalah. Hasil pengamatan secara keseluruhan diketahui bahwa rata-rata skor kemampuan guru adalah 4,60 berada pada kriteria $(4,5 \leq T K G<$ 5,0 ) yang artinya kemampuan guru dalam mengelola pembelajaran matematika dengan menggunakan modul berbasis masalah berada pada kategori sangat baik dan telah memenuhi salah satu komponen keefektifan.

b) Aktivitas Siswa

Aktivitas siswa selama proses pembelajaran diamati berdasarkan 5 kriteria aktivitas siswa yaitu: (1) Siswa membaca dan mencermati konteks masalah yang ada dalam modul, (2) Siswa membentuk kelompok untuk menyelesaikan masalah yang ada dalam modul, (3) Siswa mendiskusikan jawaban dari permasalahan yang ada bersama dengan teman kelompoknya, (4) Siswa mempresentasikan/menanggapi hasil jawaban diskusi kelompok lain dan (5) Siswa menarik kesimpulan/rangkuman dari materi yang telah dipelajari. Berdasarkan hasil analisis, diperoleh persentase aktivitas siswa selama pembelajaran adalah $75,7 \%$. Angka tersebut berada pada interval $60 \% \leq \mathrm{P}<80 \%$ dengan kategori baik. Dengan demikian, aktivitas siswa menggunakan modul berbasis masalah yang diamati telah terpenuhi.

c) Tes kemampuan masalah

Berdasarkan hasil analisis tes kemampuan masalah diperoleh informasi bahwa tes yang diikuti oleh 27 orang siswa terdapat 23 siswa mendapat skor di atas KKM, dengan nilai KKM adalah 75. Siswa termasuk kategori sedang ada $14,8 \%$ sedangkan siswa yang termasuk kategori tinggi sekitar $81,5 \%$ dan yang termasuk kategori sangat tinggi adalah 3,7\%. Dengan demikian, dapat disimpulkan bahwa skor rata-rata hasil belajar matematika seluruhnya berada dalam kategori tinggi. Berdasarkan segi ketuntasan terdapat 27 orang dari 23 siswa yang memperoleh nilai 75 ke atas. Sedangkan 4 siswa memperoleh skor di bawah 75 .

\section{Implementation (Fase Implementasi)}

Implementasi merupakan tahapan terakhir dari model penelitian dan pengembangan Plomp. Modul yang telah melewati uji kevalidan, kepraktisan dan keefektifan yang dinamakan dengan prototype III siap diimplementasikan pada keadaan sebenarnya. Implementasi modul yang dikembangkan ini masih dalam skala kecil yaitu di kelas VII SMPN 7 Cenrana yang sebelumnya dijadikan sebagai subjek uji coba produk. 


\section{SIMPULAN}

Kesimpulan yang dapat ditarik dari penelitian ini adalah modul yang dikembangkan menggunakan model pengembangan Plomp yaitu meliputi tahap Preliminary Investigation (fase investigasi awal), Design (fase desain), Realization (fase realisasi), Test, Evaluation and Revision (fase tes, evaluasi dan revisi) dan implementation (fase implementasi) untuk menghasilkan modul berbasis model pembelajaran berbasis masalah pada materi aritmatika sosial yang valid, praktis dan efektif. Kriteria valid dilihat berdasarkan hasil validasi perangkat pembelajaran berupa modul dengan rata-rata 4,3, respon siswa dengan rata-rata 4,5, respon guru dengan rata-rata 4,3, kemampuan guru mengelola pembelajaran dengan rata-rata 4,3, aktivitas siswa dengan rata-rata 4,4, Rencana Pelaksanaan Pembelajaran (RPP) dengan rata-rata 4,4 dan tes kemampuan pemecahan masalah dengan rata-rata 4,4. Masing-masing instrumen kevalidan tersebut berada pada kategori sangat valid, dengan demikian bahan ajar dan instrumen pendukungnya memenuhi kriteria valid. Kriteria praktis dilihat berdasarkan hasil analisis dari respon siswa dan respon guru. Hasil analisis data menujukkan bahwa persentase rata-rata untuk respon siswa adalah $85,53 \%$ berada pada kategori positif dan persentase rata-rata respon guru adalah $84 \%$ dan berada pada kategori sangat positif. Dengan demikian, modul yang dikembangkan memenuhi kriteria praktis. Kriteria efektif dilihat berdasarkan 3 indikator yaitu kemampuan guru dalam mengelola pembelajaran, aktivitas siswa dan tes hasil belajar. Hasil analisis data dari komponen-komponen keefektifan tersebut menunjukkan bahwa rata-rata kemampuan guru dalam mengelola pembelajaran adalah 4,63 berada pada kategori sangat baik, persentase rata-rata aktivitas siswa adalah $75,7 \%$ berada pada kategori baik, dan persentase ketuntasan belajar siswa berada pada kategori tinggi serta mencapai ketuntasan klasikal yaitu 85,2\% siswa tuntas secara klasikal. Dengan demikian, modul yang dikembangkan memenuhi kriteria efektif.

\section{DAFTAR PUSTAKA}

Al Atiyah, R. (2014). Pengaruh Penggunaan Model Pembelejaan Siklus terhadap Kemampuan Pemecahan Masalah Matematika Siswa SMP N 1 Kampar. Universitas Islam Negeri Sultan Syarif Kasim Riau.

Arsyad, A. (2015). Media Pembelajaran. Jakarta: Rajawali Pres.

Khadijah, S. (2017). Pengembangan Bahan Ajar Matematika Berbasis Masalah Untuk Memfasilitasi Pencapaian Kemampuan Pemahaman Konsep Pada Pokok Bahasan Bentuk Aljabar Kelas Vii Di Smpn 1 Sungguminasa Kab. Gowa. In Skripsi. Makassar: Fakultas Tarbiyah dan Keguruan UIN Alauddin Makassar.

Meyer, R. (1978). Designing Learning Modules for InserriceTeacher Education. Australia: Center for Advancement of Teaching.

Simanungkalit, R. H. (2016). Pengembangan Perangkat Pembelajaran untuk Meningkatkan Kemampuan Pemecahan Masalah Matematis Siswa SMP Negeri 12 Pematangsiantar. Journal of Mathematics Education, Science and Technology, 1(1), 93-56.

Soemarmo, Utari dan Hendriana, H. (2014). Penilaian Pembelajaran Matematika. Bandung: Refika Aditama.

Sumartini, T. S. (2016). Peningkatan Kemampuan Pemecahan Masalah Matematis Siswa 
Melalui Pembelajaran Berbasis Masalah. Jurnal Pendidikan Matematika, 5(2), 148158.

Syahrir, dan S. (2015). Pengembangan Modul Pembelajaran Matematika SMP. Jurnal Ilmiah Mandala Education, 1(2), 162-171.

Wulandari, Y. (2016). Penerapan Model Pembelajaran Berbasis Masalah Terhadap Kemampuan Pemecahan Masalah Matematika Siswa Di SMP Negeri 1 Padang.

Yustianingsih, R., \& Syarifuddin, H. (2017). Pengembangan Perangkat Pembelajaran Matematika Berbasis Problem Based Learning (Pbl) Untuk Meningkatkan Kemampuan Pemecahan Masalah. 1(2), 258-274. 